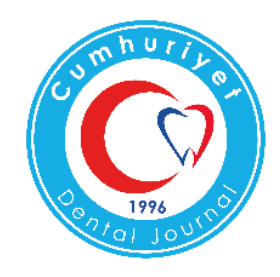

\title{
ASSESSMENT OF THE RELATIONSHIPS BETWEEN DELETERIOUS ORAL HABITS THAT MAY CAUSE ORTHODONTIC ANOMALIES AND PSYCHOLOGICAL AND SOCIO-DEMOGRAPHIC FACTORS
}

\author{
Ortodontik Anomalilere Sebep Olabilen Kötü Alışkanlıkların Psikolojik ve \\ Sosyodemografik Faktörlerle İlişkisinin Değerlendirilmesi
}

Zeynep ÇOBAN BÜYÜKBAYRAKTAR, Cenk DORUK

\begin{abstract}
Makale Kodu/Article Code : 341904
Makale Gönderilme Tarihi $\quad$ :05.10.2017

Kabul Tarihi

$\therefore 08.11 .2017$
\end{abstract}

\section{ABSTRACT}

Objectives: The aim of this study is to identify the relation between the deleterious oral habits (DOH) which can cause orthodontic anomalies such as finger sucking, nail biting, lip chewing, bruxism and psychological and sociodemographic factors.

Materials and Methods: 64 males, 71 females, between the ages of 9 and 12, including their parents have been included in our study. In our study, a survey form consisting of Clinic Examination Data Form, Sociodemographic Data Form, Children's Depression Inventory (CDI), Child State Trait Anxiety Inventory (CSTAI) has been applied to patients.

Results: DOH have been observed in $62.5 \%$ of the male children and \% 52.1 of the female children, but these results are not statistically significant $(p>0.05)$. No statistically significant association was found between DOH and CDI $(\mathrm{p}>0.05)$. No statistically significant association was found between the CSTAI status section score and trait section score and DOH ( $>0.05)$. Statistically significant associations were found between family type and DOH $(\mathrm{p}<0.05)$.

Conclusions: While there was no association between anxiety and depression and $\mathrm{DOH}$, there was significant association family type from socio-demographic factors and $\mathrm{DOH}$

Key words: Finger Sucking, Nail Biting, Depression, Anxiety
ÖZ

Amaç: $\mathrm{Bu}$ çalışmanın amacı; ortodontik anomalilere sebep olabilen, parmak emme, tırnak yeme, dudak emme, diş sıkma ve gıcırdatma gibi kötü alışkanlıkların psikolojik ve sosyodemografik faktörlerle ilişkisini saptamaktır.

Gereç ve Yöntem: Çalışmamıza, yaşları 9 ila 12 arasında değişen 64 erkek, 71 kız olmak üzere toplamda 135 çocuk ve ebeveynleri dahil edilmiştir. Çalışmamızda, Klinik Muayene Veri Formu, Sosyodemografik Veri Formu, Çocuklar İçin Depresyon Ölçeği (ÇDÖ), Çocuklar İçin Durumluk-Sürekli Kaygı Envanteri (ÇDSKE) şeklinde 4 bölümden oluşan anket formu, hastalara uygulanmıştır.

Bulgular: Erkek çocukların \%62,5'inde, kız çocukların ise \%52,1'inde kötü alışkanlık görülmüştür ancak elde edilen bu sonuç istatistiksel olarak anlamlı değildir (p>0,05). Kötü alışkanlıklar ile ÇDÖ puanı arasında istatistiksel açıdan anlamlı bir ilişki bulunamamıştır ( $p>0,05)$. ÇDSKE durumluk bölüm puanı ve sürekli bölüm puanı ile kötü alıșkanlıklar arasında istatistiksel olarak anlamlı bir ilişki bulunamamıştır ( $>00,05)$. Aile tipi ile kötü alışkanlıklar arasında ise istatistiksel açıdan anlamlı ilişki bulunmuştur $(\mathrm{p}<0,05)$.

Sonuç: Kaygı ve depresyon ile kötü alışkanlıklar arasında anlamlı bir ilişki bulunamazken, sosyodemografik faktörlerden yalnız aile tipi ile kötü alışkanlıklar arasında anlamlı bir ilişki bulunmuştur.

Anahtar kelimeler: Parmak Emme, Tirnak Yeme, Depresyon, Kayg1 


\section{INTRODUCTION}

Repetitive activities that occur automatically are called habits. These repetitive behaviors are often seen in childhood and many begin and end by themselves. ${ }^{1}$ Habits such as finger sucking and foreign body stabbing, which are sometimes part of the psychosocial development that breaks the physiological development between the ages of 3 and 6 and leads to pathology in the dentition are described as deleterious oral habits (DOH). DOH could be divided into 2 main groups:

1. Acquired DOH: When a child grows up, they can easily leave this hint of habit and switch to another habit.

2. Compulsive DOH: These habits are constantly seen in children and when emotional pressure becomes unbearable for a child, they feel secure themselves with this habit. He feels uneasy when he tries to get rid of habits. ${ }^{2}$

DOH such as finger sucking, lip chewing, mouth breathing, nail biting, tongue thrusting can be seen in children. It is known that DOH seen in children sometimes cause orthodontic anomalies that are impossible to cure. Orthodontic deformation caused by DOH varies with the severity of habits, frequency of recurrence, duration of residence and tissue strength. ${ }^{3}$

The reasons for these habits are different. Several theories (psychoanalytic theory, learning theory, insufficient sucking theory) have been proposed to explain the etiology of sucking behavior in particular. According to the psychoanalytic theory which is one of these theories, sucking behavior is instinct for the first period of life. Unhindered, it should be saturated in this period. According to those who argue that sucking behaviors that transcend the reflex or instinct dimension originate from various spiritual problems, the problem should be sought especially in child-mother or childsibling relationships. ${ }^{4,5}$ According to some experts; sucking behavior that develops to elder or older ages is a symptom of abnormal psychological development. ${ }^{5,6}$

Nail biting, which is another of the $\mathrm{DOH}$, emerges as a reaction in response to some psychological disorders and in some children it is seen that sucking habits have changed to nail biting. ${ }^{1} \quad$ Depression-style psychological problems have been identified in more than half of the families with children having nail biting. Children with this habit should be assessed emotionally.

The etiology of bruxism is still being debate and in the theories; occlusal, psychological, genetic and stress factors are emphasized. It has been abandoned to think that the phenomenon of bruxism is related to occlusal discomfort alone. Today, there is a common belief that etiology is related to more than one factor and it is thought that there is a central nervous system phenomena associated with more stress and pain behavior. ${ }^{7}$

In our study, DOH such as finger sucking, nail biting, lip chewing and bruxism were evaluated in relation to psychological and socio-demographic factors and comprehensive data on etiology of these DOH were collected.

\section{MATERIAL AND METHOD}

Our study was conducted on the children and their parents who applied to the Orthodontics Department of the Dentistry of Cumhuriyet University for examination between the dates of 10.12.2016 and 10.03.2017. In total, 135 children and their parents, 64 of whom are male and 71 of whom are female were included in to our study. The ages of the children are between 9 and 12 .

Oral and written consent with ethics committee approval for study were taken from each patient and parents (Ethics committee decision no: 2016-09/05, Date: 27.09.2016).

Patients who have not had any previous orthodontic treatment and who do not have any mental or physical disabilities that would 
prevent them from responding to the questionnaire were included in the study.

Habit group (HG): From the child patients who have at least one of the $\mathrm{DOH}$ such as finger sucking, lip chewing, nail biting and bruxism.

Habit free group (HFG): It is made up of children who have not seen any of the $\mathrm{DOH}$ mentioned.

The questionnaire consists of 4 sections (Clinical Examination Data Form, Sociodemographic Data Form, Children's Depression Inventory, Child State Trait Anxiety Inventory) in total has been applied to collect information about the underlying causes of $\mathrm{DOH}$ that described the negative effects on mouth, teeth and jaw system.

1. Clinical Examination Data Form: This section includes intra oral and extra oral examinations made by the observer and questions directed to the patients' parents. The age and gender of the patients were recorded. Whether or not DOH such as finger sucking, nail biting, bruxism and lip chewing are present or not is discussed and evaluated with the patients' parents.

2. Socio-demographic Data Form: In this section, age, education, family type, number of children living at home, settlement place and monthly income are questioned. The answers to the questions in this section are taken from the guardians of patients.

3. Children's Depression Inventory: In childhood depression, among the selfassessment scales, the most frequently used one and the most frequently researched psychometric features of a scale is the Children's Depression Inventory and it is a selfassessment scale applicable to children aged 617 years. It has been based on the views of Kovacs which are 1. There is childhood depression, 2. Observable and measurable, 3. Features similar to adults. The Beck Depression Scale is based on the questionnaire, but also includes questions about the school-specific situation for childhood depression, friendship, and so on. ${ }^{8,9}$ The scale is filled in by reading to the child or by the child. There are three different options for each item on the 27-item scale. The child is asked to choose the most appropriate sentence for the last two weeks. For example; 1 . I feel sad sometimes from time to time. 2. I feel sad often. 3. I always feel sorry for myself. Each item takes 0,1 or 2 points according to the severity of the indication. The maximum score is 54 . The higher the score, the more depressed it is. The cut point is recommended as $19 .^{8,9}$ Validity and reliability studies in our country were made by ÖY ${ }^{10}$ and pathology cut point was determined as 19 points.

\section{Children's State Trait Anxiety Inventory:} This scale, developed by Spielberger ${ }^{11}$, has two subscales with multiple choice of 20 questions for state and trait anxiety. Each item is scored 1, 2 or 3 according to the severity of the indication.

Trait Anxiety Scale: It aims to measure persistent individual differences as well as anxiety. The scale consists of 20 items. It usually evaluates how the child feels according to the frequecy of occurence. Expressions such as "My nerves at home" or "My hands are titled" are answered with one of the "almost never", "sometimes" and "often" options. The scores to be taken from the scale are between 20 and 60 , the increase of the scores represents the increase in trait anxiety.

State Anxiety Scale: The children are asked to evaluate how they feel at that moment and to choose the most appropriate option such as "I feel so angry, I feel angry, I do not feel angry". The total number of items is 20 . The lowest score you can get is 20, the highest score is 60 . The state anxiety scale is suggested to be given prior to the trait anxiety scale in practice, since it is a scale that is susceptible to emotions/ disturbances that may occur in test conditions. The study of validity and reliability of the scale in our country was carried out by Özusta. ${ }^{12}$ 
Patients in both groups were examined first, the necessary information was recorded by the investigator and than a questionnaire was given to the patients and their parents to answer socio-demographic questions and psychological inventory. Socio-demographic questions were asked to be answered by guardian of patient and psychological inventory of the patients were asked to be answered by the patient.

\section{Statistical method}

The data obtained from our study were uploaded to the SPSS (Ver: 15.0) program. In the evaluation of the data; the mean, standard deviation and frequency distributions were examined. Subsequently, the significance test between the two means in comparison of the groups, Man Whitney U and Chi Square test have been used. The level of error was taken as 0.05 .

\section{RESULTS}

The gender distribution of the children included in the study is $64(47.4 \%)$ male and $71(52.6 \%)$ female. The average age of the individual is 11.3 for males and 11.4 for females.

$62.5 \%$ of males and $52.1 \%$ of females were seen to have DOH (Table 1). There was no statistically significant association between males and females, although the percentage of malnutrition was higher in males $(\mathrm{p}>0.05)$.

Table.1 Assessment of individuals in terms of DOH and gender

\begin{tabular}{|c|c|c|c|c|c|c|}
\hline & & & & & Total & Result \\
\hline \multirow{5}{*}{ Gender } & & & HG & HFG & & 0,22 \\
\hline & \multirow{2}{*}{ Male } & $\mathrm{N}$ & 40 & 24 & 64 & \\
\hline & & $\%$ & 62,5 & 37,5 & 100 & \\
\hline & \multirow{2}{*}{ Female } & $\mathrm{N}$ & 37 & 34 & 71 & \\
\hline & & $\%$ & 52,1 & 47,9 & 100 & \\
\hline \multirow{2}{*}{ Result } & & $\mathrm{N}$ & 77 & 58 & 135 & \\
\hline & & $\%$ & 57 & 43 & 100 & \\
\hline
\end{tabular}

The average score of CDI is higher in individuals with DOH (Table 2), but no statistically significant association was found between DOH and CDI scores ( $p>0.05$ ).
Table.2 Assessment of individuals in terms of DOH and CDI score

\begin{tabular}{|c|c|c|c|c|c|c|}
\hline DOH & N & Average & SD & Minimum & Maximum & Median \\
\hline HG & 77 & 9,8312 & 5,46135 & 1,00 & 33,00 & 9,0000 \\
\hline HFG & 58 & 9,0345 & 6,20686 & 2,00 & 37,00 & 7,0000 \\
\hline Total & 135 & 9,4889 & 5,78452 & 1,00 & 37,00 & 8,0000 \\
\hline
\end{tabular}

$\mathrm{p}=0.160$

CSTAI state and trait anxiety scale point averages were found higher in individuals with DOH as seen on Table 3 and Table 4. No statistically significant association was found between CSTAI status and trait episode score and $\mathrm{DOH}(\mathrm{p}>0.05)$.

Table.31 Assessment of individuals in terms of DOH and CSTAI State Scale score

\begin{tabular}{|l|l|l|l|l|l|l|}
\hline DOH & $\mathrm{N}$ & Average & SD & Minimum & Maximum & Median \\
\hline HG & 77 & 31,0390 & 6,51606 & 23,00 & 50,00 & 28,0000 \\
\hline HFG & 58 & 29,5690 & 5,42933 & 21,00 & 40,00 & 26,0000 \\
\hline Total & 135 & 30,4074 & 6,09538 & 20,00 & 50,00 & 30,0000 \\
\hline
\end{tabular}

$\mathrm{p}=0.090$

Table.4 Assessment of individuals in terms of DOH and CSTAI Trait Scale score

\begin{tabular}{|c|c|c|c|c|c|c|}
\hline DOH & N & Average & SD & Minimum & Maximum & Median \\
\hline HG & 77 & 34,1299 & 8,05957 & 28,00 & 55,00 & 30,0000 \\
\hline HFG & 58 & 33,6034 & 6,44529 & 24,00 & 50,00 & 28,0000 \\
\hline Total & 135 & 33,9037 & 7,38784 & 20,00 & 55,00 & 33,0000 \\
\hline
\end{tabular}

$\mathrm{p}=0.894$

Among the parameters such as age, educational status, family type, number of children living at home, place of residence and monthly income of parents and siblings questioned in the socio-demographic data form, only "family type" was found to have a significant association with DOH $(\mathrm{p}<0.05)$, (Table 5).

Table.5 Assessment of individuals in terms of DOH and family type

\begin{tabular}{|l|l|c|c|c|c|l|}
\hline & & & \multicolumn{2}{|c|}{ DOH } & Total & Result \\
\hline \multirow{4}{*}{$\begin{array}{l}\text { Family } \\
\text { Type }\end{array}$} & Nuclear Family & N & 53 & 50 & 103 & \\
\cline { 2 - 6 } & & $\%$ & 51,5 & 48,5 & 100 & \\
\cline { 2 - 6 } & \multirow{2}{*}{ Other Group* } & N & 24 & 8 & 32 & \\
\cline { 3 - 6 } & & $\%$ & 75 & 25 & 100 & \\
\hline \multirow{3}{*}{} & \multirow{2}{*}{ Total } & N & 77 & 58 & 135 & \\
\cline { 3 - 6 } & & 57 & 43 & 100 & \\
\hline
\end{tabular}

* Fragmented or extended family $\mathrm{x}^{2}=5.523 \quad \mathrm{p}=0.01$

\section{DISCUSSION}

135 individuals and their parents, aged 9-12 years, were included in the study. The reason we choose age range 9-12 is that the Children State- 
Trait Anxiety Inventory we use in our study is applicable to this age range.

In our study, the rate of DOH in males was found higher than females. In the study done by Leme et al., the rate of DOH was found higher in girls than in boys ${ }^{8}$, but in some other studies there was no significant relationship between males and females in terms of DOH. ${ }^{9,10}$ Until now, there is no consensus in the literature as to whether there is a relationship between gender and DOH. This can be explained by the psychological character difference seen in the individuals participating in the study.

Two theories have been proposed to describe the etiology of DOH. One of them is the psychoanalytic theory, which is defended by Freud, and the other is the theory of learning. ${ }^{11}$ The link between psychoanalytic theory and DOH remains unclear in the literature. The work done in this subject is limited. ${ }^{12}$ We need studies which are about psychosocial variables such as depression and anxiety, which are frequently seen in children and adolescents with DOH. Thus, in our study, Children's Depression Inventory which is used frequently and Children's State Trait Anxiety Inventory which is used for determining anxiety levels have been used.

There was no statistically significant relationship between anxiety and $\mathrm{DOH}$ in our study; but CSTAI scores were found higher in individuals with DOH. Similarly, in a study by Dellazzana et al., it is found that anxiety scores were higher in children with oral habits, especially with mouth / tongue biting. ${ }^{13}$ Unlike our study, Leme et al. and Tanaka et al. found a significant relationship between $\mathrm{DOH}$ and anxiety in their work. ${ }^{12}$

Although there was no statistically significant relationship between depression and oral habits in our study the average score of depression in individuals with oral habits was found to be higher. Similarly, in the study done by Leme et al. there have been found more depressive symptoms in children and adolescents with oral habits when compared to those not seen. ${ }^{8}$

Mothers and fathers are the individuals having a basic role in child development. A child modeling his or her parents can develop positive or negative personality traits. The increase in the socioeconomic level also causes the individual to feel more comfortable and stronger in the society, to trust himself and his family, and to be accepted around his friends. Otherwise, adjustment problems and behavioral disorders may develop in children. ${ }^{14}$ Therefore, the relationship between $\mathrm{DOH}$ and sociodemographic factors was evaluated and there was no statistically significant relationship between DOH and mother's age, father's age, mother's educational status, father's educational status, number of children living at home, place of residence and monthly income.

In a study similar to our study in 2009 when we look at their compliance problems according totheir habitual disorders of the students of the schools at different socioeconomic levels, statistically significant difference couldn't be found when lower, middle, upper socioeconomic levels are compared according to variables of night wetting, finger sucking, nail biting. ${ }^{15}$ Unlike our study, in a study of the relationship between socioeconomic factors and oral habits, it was found that there are more oral habits in the children of the parents having low socioeconomic conditions. This is due to the high likelihood that parents with low socioeconomic conditions may not have adequate information about oral health and problems that may arise in the presence of oral habits. ${ }^{9}$

There are many reasons why children experience adjustment and behavior disorders. One of these reasons is the divorce of parents or the fragmentation of family. Family type has a significant effect on the development of children. There was a statistically significant relationship between family type and DOH in 
our study. ${ }^{16}$ In a similar research on primary school students with different socioeconomic conditions in Malatya province center, when those with compliance problems and those with no compliance problems are compared, it has been determined that there is differences from the aspects of tic, nail biting, finger sucking, night wetting and school achievement. These problems were more frequently observed in those with adjustment problems, and school performance was found to be lower in these children. ${ }^{17}$ This data overlaps with the data obtained with our work.

\section{CONCLUSION}

There was no statistically significant relationship between anxiety and $\mathrm{DOH}$; however, the scores of CSTAI were found higher in individuals with DOH. Despite the fact that there is no statistically significant relationship between depression and $\mathrm{DOH}$, the average score of depression in individuals with oral habits is higher. There was a statistically significant relationship between family type and $\mathrm{DOH}$.

It seems beneficial for us that there must be done more comprehensive studies including consultation with psychiatric departments in larger patient groups about the relationship between DOH and psychological and sociodemographic factors.

\section{REFERENCES}

1. Shahraki N, Yassaei S, Moghadam MG. Abnormal oral habits: a review. Journal of Dentistry and Oral Hygiene 2012;2:12-15.

2. Finn SB. Clinical pedodontics. Saunders. Philadelphia, 1998:370-80.

3. Enünlü N. Ortodontide kötü alışkanlıkların önemi (tipik bir vak'a münasebetiyle)-The Role of bad habits in orthodontics (report of a rare case). Journal of Istanbul University Faculty of Dentistry 1972;1:57-64.
4. Friman P. Thumb sucking in childhood, feelings and their medical significance. 1987;29:11-14.

5. Haryett R, et al. Chronic thumb-sucking: the psychologic effects and the relative effectiveness of various methods of treatment. American Journal of Orthodontics 1967;8:569585 .

6. Hanna JC. Breast feeding versus bottle feeding in relation to oral habits. Journal of Dentistry for Children 1967;4:243-249.

7. Carlsson GE, Egermark I, Magnusson T. Predictors of bruxism, other oral parafunctions, and tooth wear over a 20-year follow-up period. Journal of Orofacial Pain 2003;17(1).

8. Leme $\mathrm{M}$, et al. Associations between psychological factors and the presence of deleterious oral habits in children and adolescents. Journal of Clinical Pediatric Dentistry 2014;4:313-317.

9. Facciolli Hebling SR, et al. Relationship between malocclusion and behavioral, demographic and socioeconomic variables: a cross-sectional study of 5-year-olds. Journal of Clinical Pediatric Dentistry 2008;1:75-79.

10. Stahl F, et al. Relationship between occlusal findings and orofacial myofunctional status in primary and mixed dentition. Journal of Orofacial Orthopedics/Fortschritte der Kieferorthopädie 2007;2:74-90.

11. Johnson E, Larson B. Thumb-sucking: literature review. Journal of Dentistry for Children 1993;6:385-391.

12. Tanaka OM, et al. Nailbiting, or onychophagia: a special habit. American Journal of Orthodontics and Dentofacial Orthopedics 2008; 2:305-308.

13. Dellazzana AA, et al. Deleterious oral habits: relationship with the z-score boby mass index and anxiety in children. Revista Conhecimento Online, 2017; 1:3-11. 
14. Çetinkaya $\mathrm{S}$, et al. Sivas il merkezinde sosyoekonomik düzeyi farklı üç ilköğretim okulu öğrencilerinin benlik saygısı düzeyi. Klinik Psikiyatri 2006; 9:116-122.

15. Selimhocaoğlu A. Farklı sosyo-ekonomik düzeylerdeki ilköğretim okullarında okuyan öğrencilerin anne-babalarının değerlendirmesine göre uyum sorunları (Kırşehir İl Örneği). Türk Psikolojik Danışma ve Rehberlik Dergisi 2016;4 (32).

16. Aber JL, Jones S, Cohen J. The impact of poverty on the mental health and development of very young children. 2000 .

17.Kaya $\mathrm{M}$, et al. Malatya il merkezinde farklı sosyoekonomik düzeydeki iki ilköğretim okulunda demir eksikliği anemisi yaygınlığı. 2006.

\section{İletişim Adresi}

\section{Zeynep ÇOBAN BÜYÜKBAYRAKTAR}

Cumhuriyet Üniversitesi

Diş Hekimliği Fakültesi

Ortodonti ABD

Sivas, Türkiye

Tel: +905548005191

E-mail: dtzeynepcoban@gmail.com 